\title{
Perbandingan Tingkat Akurasi Metode KNN Dan Decision Tree Dalam Memprediksi Lama Studi Mahasiswa
}

\author{
Endang Etriyanti \\ Sistem Informasi, STMIK Bina Nusantara Jaya Lubuklinggau \\ Jl. Yos Sudarso No. 97 A, Kota Lubuklinggau, Sumatera Selatan \\ Telp : 081996312599 \\ E-mail : endang.etriyanti@gmail.com
}

\begin{abstract}
One of the qualities of graduates from a tertiary institution can be seen from the length of study of students. In addition, the length of study for students illustrates the level of student achievement in their education. The length of study also greatly affects the quality of the study program because the length of study for students is one of the criteria for accreditation assessment. Often the problem faced by a university is the number of students who complete their education in more than the specified time period. STMIK Bina Nusantara Jaya Lubuklinggau also experienced this. To anticipate this, it is necessary to predict the length of study for students because the length of study for students is one of the important things that need to be considered in the study program section of a university. This research contributes theoretically to the implementation of data mining to predict student study time. This research applies data preprocessing to obtain good quality data before the mining process is carried out using the K-Nearest Neighbor and Decision Tree methods on the Rapid Miner Tools, both methods are validated using the K-Fold. Cross Validation (with 10 iterations / repetitions) and Confusion Matrix are used to validate the accuracy of the predicted results. The highest accuracy value from the results of the application of the two methods will be recommended to solve the problem of predicting student study time. From the research results, the accuracy value of the Decision Tree method (60.38\%) is better than the accuracy value of the K-Nearest Neighbor method (53.08\%).
\end{abstract}

Keywords: Predictionsi, Lenght of Study, K-Nearest Neighbor, Decision Tree

\begin{abstract}
Abstrak
Kualitas lulusan dari sebuah Perguruan Tinggi salah satunya dapat dilihat dari lama studi mahasiswa. Selain itu lama studi mahasiswa menggambarkan tingkat capaian mahasiswa dalam pendidikannya. Lama studi juga sangat berpengaruh pada kualitas program studi karena lama studi mahasiswa merupakan salah satu kriteria penilaian akreditasi. Seringkali masalah yang dihadapi oleh suatu Perguruan Tinggi adalah banyaknya mahasiswa yang menyelesaikan pendidikannya lebih dari jangka waktu yang ditetapkan. STMIK Bina Nusantara Jaya Lubuklinggau juga mengalami hal tersebut. Untuk mengantisipasi hal tersebut perlu adanya prediksi lama studi mahasiswa karena lama studi mahasiswa menjadi salah satu hal yang penting yang perlu diperhatikan bagian program studi dalam suatu Perguruan Tinggi. Penelitian ini berkontribusi secara teoretis dalam implementasi data mining untuk memprediksi lama studi mahasiswa.Penelitian ini menerapkan preprocessing data untuk memperoleh data dengan kualitas baik sebelum dilakukan proses mining menggunakan metode $K$-Nearest Neighbor dan Decision Tree pada Tools RapidMiner, kedua metode divalidasi menggunakan K-Fold Cross Validation (dengan 10 kali iterasi/pengulangan) dan Confusion Matrix digunakan untuk memvalidasi nilai akurasi hasil prediksi. Nilai akurasi yang paling tinggi dari hasil penerapan kedua metode akan direkomendasikan untuk menyelesaikan masalah prediksi lama studi mahasiswa. Dari hasil penelitian diperoleh nilai akurasi metode Decision Tree (60,38\%) lebih baik jika dibandingkan dengan nilai akurasi metode $K$-Nearest Neighbor $(53,08 \%)$.
\end{abstract}

Kata kunci: Prediksi, Lama Studi, K-Nearest Neighbor, Decision Tree

\section{Pendahuluan}

Kualitas lulusan dari sebuah Perguruan Tinggi salah satunya dapat dilihat dari lama studi mahasiswa. Selain itu lama studi mahasiswa menggambarkan tingkat capaian mahasiswa dalam pendidikannya. Lama studi juga sangat berpengaruh pada kualitas program studi karena lama studi mahasiswa merupakan salah satu kriteria penilaian akreditasi [1]. Lama studi merupakan jangka waktu yang diperlukan mahasiswa dalam menyelesaikan pendidikanya. Lama studi mahasiswa telah diatur dalam ketetapan Kementerian Pendidikan dan Kebudayaan Direktorat Jenderal Pendidikan Tinggi tentang Sistem Pendidikan Tinggi yang menyatakan bahwa untuk memenuhi standar kompetensi lulusan bagi mahasiswa program sarjana (S1) beban wajib yang harus ditempuh adalah paling sedikit 144 - 160 satuan kredit semester (sks) dengan lama studi selama 8 - 10 semester atau 4 - 5 tahun [2]. Oleh karena itu lama studi mahasiswa menjadi salah satu hal yang penting yang perlu diperhatikan bagian program studi dalam suatu Perguruan Tinggi. 
Seringkali masalah yang dihadapi oleh suatu Perguruan hasil penelitian Decision Tree memiliki nilai akurasi Tinggi adalah banyaknya mahasiswa yang 76,69\% dan K-Nearert Neighbor yaitu 69,82\%. menyelesaikan pendidikannya lebih dari jangka waktu yang ditetapkan. Hal tersebut juga dialami oleh STMIK Berdasarkan uraian diatas, penelitian ini bertujuan untuk Bina Nusantara Jaya Lubuklinggau. Banyaknya melakukan prediksi lama studi mahasiswa STMIK Bina mahasiswa yang menyelesaikan masa pendidikannya Nusantara Jaya dengan 2 metode yaitu Decision Tree lebih dari jangka waktu yang ditetapkan mengakibatkan dan K-Nearest Neighbor. Pada penelitian ini data yang turunnya mutu lulusan [2]. Untuk mengantisipasi hal digunakan berjumlah 260 data mahasiswa program studi tersebut perlu adanya prediksi lama studi mahasiswa. Sistem Informasi tahun angkatan 2013 s.d. 2015 yang Jika lama studi mahasiswa dapat diprediksi maka bagian telah menyelesaikan masa studinya. Penelitian ini program studi dapat mengambil tindakan/keputusan berkontribusi secara teoretis dalam implementasi data untuk mengantisipasi banyaknya mahasiswa yang mining untuk memprediksi lama studi mahasiswa. diprediksi masa studinya lebih dari waktu yang Selain itu, penelitian ini diharapkan dapat memberi ditetapkan tersebut.

manfaat bagi institusi untuk dapat mengantisipasi banyaknya mahasiswa yang tidak mampu

[3] mendefinisikan prediksi sebagai proses keilmuan menyelesaikan pendidikanya sesuai waktu yang untuk mendapatkan knowledge secara berurutan ditetapkan.

berdasarkan bukti-bukti. Sedangkan [4] mendefinisikan prediksi hampir sama dengan klasifikasi dan estimasi, 2. Tinjauan Pustaka hanya saja prediksi digunakan untuk menduga nilai-nilai tertentu yang akan terjadi dimasa mendatang. Salah satu 2.1 Data Mining cara untuk menyelesaikan masalah prediksi adalah menggunakan teknik data mining. Data mining merupakan cabang ilmu baru untuk mengatasi masalah pengalian informasi atau pola yang penting atau menarik [1] dan pengetahuan abstrak dari sebuah database yang besar [5] yang meliputi bentuk dan/atau hubungan antar data. [6] juga mendefinisikan data mining sebagai proses ektraksi informasi untuk memperoleh pengetahuan dan menemukan pola pada tumpukan data berskala besar. Dari beberapa definisi di atas dapat disimpulkan bahwa data mining merupakan proses menganalisa data dalam jumlah yang besar menjadi suatu informasi yang lebih bermakna.

Data mining merupakan cabang ilmu baru untuk mengatasi masalah penggalian informasi atau pola yang penting atau menarik dari data dalam jumlah besar [1]. Ada pula yang menyatakan bahwa data mining adalah proses ektraksi informasi untuk memperoleh pengetahuan dan menentukan pola pada tumpukan data dalam database berskala besar [6]. Dan [10] mendefinisikan data mining sebagai bidang ilmu untuk proses mendapatkan pengetahuan atau pola dari basis data, sehingga dapat dijadikan solusi pengambilan keputusan.

\subsection{K-Nearest Neighbor}

Ada banyak metode data mining yang dapat diterapkan $K$-Nearest Neighbor (KNN) merupakan algoritma yang untuk menyelesaikan masalah prediksi. Algoritme yang berfungsi untuk mengklasifikasikan suatu data populer antara lain Artificial Neural Network, berdasarkan data pembelajaran (train data sets), yang Algoritme C4.5, Nearest Neighbour Rule, Fuzzy Logic, diambil dari K tetangga terdekatnya (nearest neighbor), Naive Bayes, K-Mean, Support Vector Machine, dan dengan K adalah banyaknya tetangga terdekat [8]. lain-lain. Penelitian yang mengangkat topik tentang Dengan kata lain tujuan dari algoritma ini yaitu prediksi dan mengukur tingkat akurasi masing-masing mengklasifikasikan objek baru berdasarkan atribut dan metode data mining. telah banyak dilakukan sample dari data training. Contoh kasus, misalkan untuk sebelumnya. Penelitian [7] dan [8] membandingkan memprediksi lama studi mahasiswa digunakan data kinerja antara Algoritma K-Nearest Neighbor dengan mahasiswa yang telah menyelesaikan masa studinya.

Decision Tree dalam melakukan prediksi. Temuan dari penelitian tersebut menunjukan tingkat akurasi metode Algoritma Decision Tree lebih baik dibandingkan dengan $K$-Nearest Neighbor. Hasil yang sama diperoleh pada penelitian [9] membandingkan metode data mining untuk memprediksi mahasiswa lulus tepat waktu dengan menggunakan tiga metode yaitu Decision Tree, Naive Bayes Classifier dan K-Nearert Neighbor. Secara berturut-turut diperoleh tingkat akurasi sebesar 98.04\%, $96 \%$ dan $90 \%$. Pada penelitian [10] juga menunjukkan bahwa menunjukan tingkat akurasi metode Algoritma Decision Tree lebih baik dibandingkan dengan K-Nearest Neighbor. Dan pada penelitian [4] memprediksi kelulusan tepat waktu mahasiswa, dengan

\section{Tahapan metode KNN [8]:}

1) Penentuan nilai $K$;

2) Perhitungan jarak antar data training dan data testing (uji). Perhitungan jarakke tetangga menggunakan algoritma euclidean seperti pada persamaan 1:

3) Pengurutan data hasil perhitungan;

4) Menentukan kelompok data hasil uji berdasarkan label mayoritas dari K tetangga terdekat. 


\subsection{Decision Tree}

Decision Tree atau pohon keputusan merupakan alat pendukung keputusan yang menggunakan model keputusan yang berbentuk seperti pohon [8]. Decision Tree memprediksi sebuah kelas (klasifikasi) atau nilai (regresi) berdasarkan aturan-aturan yang dibentuk setelah mempelajari data [7].

Tahapan metode Decision Tree [8]:

1) Pilih atribut sebagai simpul akar;

2) Buat cabang untuk tiap-tiap nilai;

3) Bagi kasus dalam cabang;

4) Ulangi proses untuk setiap cabang sampai semua kasus pada cabang memiliki kelas yang sama;

5) Pemilihan atribut sebagai simpul, baik akar (root) atau simpul internal didasarkan pada nilai gain tertinggi dari atribut-atribut yang ada.

\subsection{RapidMiner}

Dalam melaksanakan proses mining biasanya digunakan Metode penelitian digunakan sebagai acuan atau alat bantu berupa software. Salah satu alat bantu tersebut kerangka proses penelitian sehingga rangkaian proses adalah RapidMiner. RapidMiner digunakan untuk penelitian dapat dilakukan secara sistematis dan terarah merancang aliran secara visual untuk menganalisis data [13]. Tahap pertama yang dilakukan adalah science dan machine learning di dalam tim mulai dari pengumpulan data. Data yang diperoleh adalah analis hingga pakar.

Dalam penggunaannya Rapidminer tergolong mudah atribut. Tahap kedua dilakukan preprocessing data atau untuk digunakan mulai dari kempuannya untuk pengolahan data awal untuk mendapatkan data yang mengumpulkan data dari berbagai sumber, eksplorasi baik sebelum data diolah menggunakan menggunakan data secara statistik, tersedianya berbagai macam model metode Decision Tree dan K-Nearest Neighbor. Setelah mechine learning dan model validasi.

\subsection{Prediksi}

[4] mendefinisikan prediksi hampir sama dengan klasifikasi dan estimasi, hanya saja prediksi digunakan untuk menduga nilai-nilai tertentu yang akan terjadi dimasa mendatang. [3] juga mendefinisikan prediksi sebagai proses keilmuan untuk mendapatkan knowledge secara berurutan berdasarkan bukti-bukti.

\subsection{K-Fold Cross-Validation}

K-Fold Cross Validation digunakan untuk memvalidasi nilai akurasi kedua metode yang diterapkan. Teknik ini diterapkan dengan membagi data menjadi $\mathrm{k}$ bagian (folds), satu bagian digunakan untuk pengujian dan dan sisanya (k-1 folds) untuk pemasangan model dengan proses iterasi dilakukan sampai seluruh folds digunakan sebagai pengujian [6]. [11] mendefinisikan K-Fold Cross Validation sebagai teknik validasi dengan membagi data secara acak ke dalam $\mathrm{k}$ bagian dan masing-masing bagian akan dilakukan proses klasifikasi, dengan teknik ini akan dilakukan pengujian sebanyak k. Secara umum pengujian nilai k dilakukan sebanyak 10 kali untuk memperkirakan akurasi estimasi. sebanyak 326 data set mahasiswa tahun angkatan 2013 s.d. 2015 yang telah menyelesaikan studinya dengan 11

Confusion matrix merupakan matrix dua dimensi yang ngambarkan perbandingan antara hasil prediksi Confu kenyataan [11]. [4] juga menyatakan bahwa digunakan untuk melakukan evaluasi terhadap model klasifikasi berdasarkan perhitungan objek mana yang diprediksi benar dan tidak benar.

Confusion Matrix digunakan untuk mengevaluasi mengukur performa medel klasifikasi dilakukan dengan membandingkan seluruh data uji yang diklasifikasikan benar dengan banyaknya data uji [6]. Akurasi adalah tingkat kedekatan nilai prediksi dengan nilai aktual (sebenarnya).

\section{Metodologi Penelitian}

preprocessing data dilakukan maka data set yang diperoleh adalah 260 data mahasiswa dengan 9 atribut. Tahap ketiga, proses mining dilakukan menggunakan metode Decision Tree dan K-Nearest Neighbor pada tools RapidMiner. Penerapan tehnik K-Fold Cross Validation digunakan untuk memvalidasi nilai akurasi kedua metode yang diterapkan dan tingkat akurasi dapat dilihat berdasarkan Confusion Matrix. Tahap terakhir yaitu hasil pengujian dari metode Decision Tree dan $K$-Nearest Neighbor akan dibandingkan, dengan tujuan untuk mengetahui metode terbaik dengan melihat tingkat akurasi yang paling tinggi.

Metode penelitian yang diusulkan tersebut dapat digambarkan seperti pada Gambar 1 berikut: kuran rasio prediksi yang benar terhadap total jumlah 


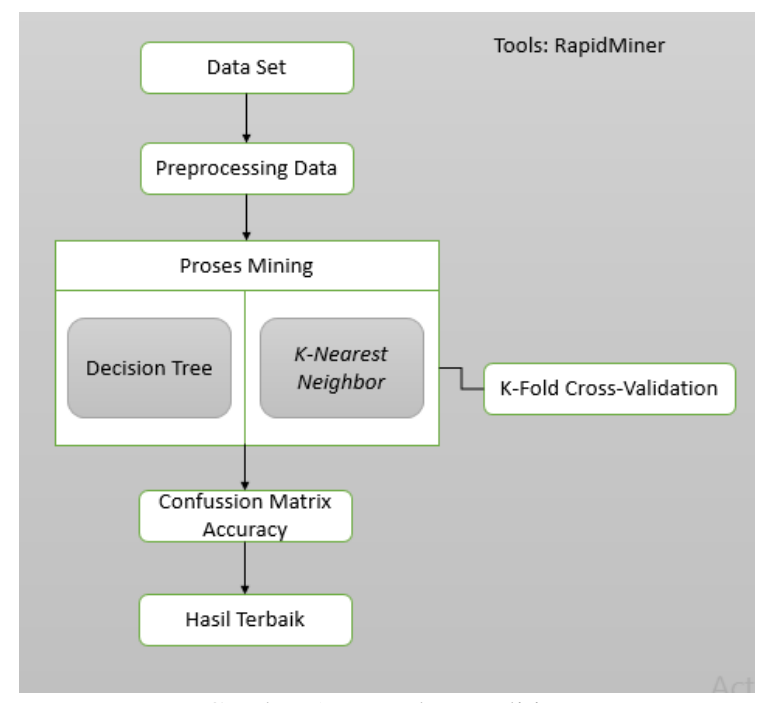

Gambar 1. Metode Penelitian

\subsection{Pengumpulan Data}

Penelitian ini menggunakan data mahasiswa program studi Sistem Informasi tahun angkatan 2013 s.d. 2015 yang telah menyelesaikan masa studinya. Data diperoleh dari bagian akademik sebanyak 326 data set mahasiswa dengan 11 atribut atau variabel. Variabel yang digunakan antara lain adalah NIM, Nama, Jenis Kelamin, Status Sekolah, Asal Sekolah, IP semester 1, IP semester 2, IP semester 3, IP semester 4, IPK semester 4 dan Lama Studi. Contoh data set yang digunakan dalam penelitian seperti pada gambar 2 berikut:

\begin{tabular}{|c|c|c|c|c|c|c|c|c|c|c|}
\hline No. & NIM & Nama Mahasiswa & Jenis Kelamin & IP-S1 & ... & IP-S4 & $\begin{array}{l}\text { IPK- } \\
\text { S4 }\end{array}$ & $\begin{array}{c}\text { Status } \\
\text { Sekolah }\end{array}$ & $\begin{array}{c}\text { Asal } \\
\text { Sekolah }\end{array}$ & $\begin{array}{l}\text { Lama } \\
\text { Studi }\end{array}$ \\
\hline 1 & 2013.01.0001 & Ahmad Shalihin & Laki-laki & 3,41 & ... & 3,18 & 3,2 & Swasta & SMA & 4 \\
\hline 2 & 2013.01.0003 & Irma Tilawati & Perempuan & 3,23 & ... & 3,1 & 3,1 & Negeri & SMA & 4 \\
\hline 3 & 2013.01.0004 & $\begin{array}{l}\text { Muhammad } \\
\text { Hidavatullah }\end{array}$ & Laki-laki & 3,27 & ... & 3,14 & 3,1 & Negeri & SMK & 4 \\
\hline 4 & 2013.01.0005 & Nurhidayah & Perempuan & 3,32 & ... & 3,05 & 3,1 & Negeri & SMK & 4 \\
\hline 5 & 2013.01.0006 & Sutrisno Raja Guk Guk & Laki-laki & 3,18 & ... & 3,06 & 3,1 & Negeri & SMA & 4 \\
\hline 6 & 2013.01.0007 & Feri Dona Putra & Laki-laki & 2,64 & $\ldots$ & 1,4 & 2,4 & Negeri & SMK & $>4$ \\
\hline 7 & 2013.01.0008 & Duwi Santoso & Laki-laki & 2,91 & $\ldots$ & 2,29 & 2,3 & Swasta & SMK & $>4$ \\
\hline 8 & 2013.01.0009 & Hesti Kurnia & Perempuan & 3,05 & $\ldots$ & 3 & 2,9 & Negeri & SMK & $>4$ \\
\hline 9 & 2013.01.0010 & Edi Lianto & Laki-laki & 3,73 & ... & 3,58 & 3,6 & Negeri & SMA & 3,5 \\
\hline 10 & 2013.01.0011 & Rina & Perempuan & 3,59 & $\ldots$ & 3,75 & 3,8 & Swasta & SMA & 4 \\
\hline
\end{tabular}

Gambar 2. Data Set
Dari hasil pengumpulan data diperoleh sebanyak 326 data set mahasiswa tahun angkatan 2013 s.d. 2015 yang telah menyelesaikan masa studinya dengan 11 atribut. Namun tidak seluruhnya data record dan atribut tersebut dapat digunakan karena perlu dilakukan tahap preprocessing data atau pengolahan awal data untuk mendapatkan data set dengan kualitas baik. Adapun rincian 11 atribut yang belum dilakukan preprocessing data terlihat seperti dalam Tabel 1 berikut:

\begin{tabular}{lll}
\multicolumn{3}{c}{ Tabel.1 Atribut Sebelum Preprocessing Data } \\
\hline No & \multicolumn{1}{c}{ Nama } & \multicolumn{1}{c}{ Jenis Data } \\
\hline 1 & NIM & Karakter \\
2 & Nama & Karakter \\
3 & Jenis Kelamin & Kategorikal \\
4 & Status Sekolah & Kategorikal \\
5 & Asal Sekolah & Kategorikal \\
6 & IP-S1 & Numerik \\
7 & IP-S2 & Numerik \\
8 & IP-S3 & Numerik \\
9 & IP-S4 & Numerik \\
10 & IPK-S4 & Numerik \\
11 & Lama Studi & Kategorikal \\
\hline
\end{tabular}

Pentingnya preprocessing data diuraikan pada beberapa penelitian berikut. Seperti penelitian yang dilakukan oleh [4] yang menyatakan bahwa teknik preproccesing dilakukan agar kualitas data yang diperoleh lebih baik dengan cara: data validation dan data discretization. Selanjutnya [7] dalam penelitiannya menerapkan preprocessing data yang dilakukan dengan data cleaning. Dan dalam penelitian yang dilakukan oleh [14] menyatakan pentingnya preproccesing data sebelum data siap diolah. Dalam penelitiannya preproccesing meliputi proses cleaning yaitu membuang duplikasi data dan memperbaiki kesalahan pada data, transformasi data yaitu mengubah nilai variabel ke format yang sesuai, dan mereduksi data yaitu data yang hanya mempunyai atribut yang berhubungan saja yang akan digunakan.

Berdasarkan pada beberapa penelitian di atas, maka pada penelitian ini preprocessing data dilakukan untuk mendapatkan data dengan kualitas baik. Preprocessing data yang penulis gunakan antara lain seperti pada tabel 2 berikut:

\subsection{Preprocessing Data}

Dalam penelitian ini prediksi dilakukan menggunakan data mahasiswa yang telah menyelesaikan masa studinya. Sehingga data yang yang digunakan dalam penelitian ini telah memiliki variabel tujuan yaitu lama studi yang dikategorikan menjadi 3 (tiga) yaitu lama studi 3.5 tahun, 4 tahun dan > 4 tahun. Hal ini dimaksudkan agar dapat diketahui nilai akurasi hasil prediksi berdasarkan penerapan dari dua metode data mining yang digunakan. Penelitian ini sejalan dengan penelitian [4] penelitian tersebut menggunakan data alumni mahasiswa sebagai data set. 
Tabel.2 Preprocessing Data

\begin{tabular}{|c|c|c|}
\hline No & Kegiatan & Tujuan \\
\hline 1 & $\begin{array}{l}\text { Pembersihan } \\
\text { Data }\end{array}$ & $\begin{array}{l}\text { Menghilangkan (menghapus) } \\
\text { data yang kosong dan tidak } \\
\text { lengkap untuk menghindari } \\
\text { adanya missing value dalam } \\
\text { data set. }\end{array}$ \\
\hline 2 & Reduksi Data & $\begin{array}{l}\text { Dilakukan guna mendapatkan } \\
\text { data set dengan record dan } \\
\text { jumlah atribut yang bersifat } \\
\text { informatif saja. Sebagai contoh } \\
\text { atribut NIM dan Nama tidak } \\
\text { digunakan pada proses mining } \\
\text { karena tidak relevan. }\end{array}$ \\
\hline 3 & $\begin{array}{l}\text { Transformasi } \\
\text { Data }\end{array}$ & $\begin{array}{l}\text { digunakan untuk mengubah IP- } \\
\text { S1, IP-S2, IP-S3, IP-S4 dan } \\
\text { IPK-S4 yaitu nilainya } \\
\text { dibuatkan interval yang lebar } \\
\text { dan kedalamannya sama. } \\
\text { Implementasi dilakukan pada } \\
\text { tool RapidMiner, } \\
\text { preprocessing data dilakukan } \\
\text { menggunakan operator } \\
\text { Discretize. }\end{array}$ \\
\hline
\end{tabular}

Setelah dilakukan preprocessing data, maka data set yang digunakan pada proses mining adalah 162 data mahasiswa dengan 9 atribut yang telah dinormalisasi dan missing value tidak terdapat pada data set tersebut. Adapun rincian atribut yang digunakan pada proses mining terlihat seperti pada Tabel 3:

Tabel 3. Atribut Data Setelah Preprocessing Data

\begin{tabular}{lll}
\hline No & Nama & Jenis Data \\
\hline 1 & Jenis Kelamin & Kategorikal \\
2 & Status Sekolah & Kategorikal \\
3 & Asal Sekolah & Kategorikal \\
4 & IP-S1 & Numerik \\
5 & IP-S2 & Numerik \\
6 & IP-S3 & Numerik \\
7 & IP-S4 & Numerik \\
8 & IPK-S4 & Numerik \\
9 & Lama Studi & Kategorikal \\
\hline
\end{tabular}

\subsection{Proses Mining dan Validasi Nilai Akurasi}

Proses mining diterapkan pada Tools RapidMiner 5.3 menggunakan metode perhitungan K-Nearest Neighbor dan Decision Tree. Dan validasi tingkat akurasi kedua metode dilakukan dengan cara menambahkan operator $X$-Validation (k-Fold Cross Validation) dengan melakukan 10 kali iterasi atau pengulangan ( $\mathrm{k}=10$ fold). Dalam 10 kali iterasi data dibagi menjadi 10 subset data. Dari 10 subset data tersebut Cross-Validation akan menggunakan 9 fold untuk pelatihan dan 1 fold untuk untuk pengujian.

\subsection{Evaluasi Tingkat Akurasi}

Nilai akurasi dari hasil pengujian dapat dilihat berdasarkan Confussion Matrik seperti pada Gambar 7 dan Gambar 11. Tabel matrix menanpilkan hasil evaluasi model klasifikasi. Misalnya data set terbagi menjadi kelas A dan kelas B, maka kelas A diasumsikan sebagai variabel positif dan kelas B diasumsikan sebagai variabel negatif. Nilai accuracy, reccal dan precission dapat diperoleh dari hasil evaluasi menggunakan Confusion Matrix. Gambar 3 merupakan contoh Confusion Matrix:

Kelas Hasil Prediksi

\begin{tabular}{|c|c|c|c|}
\hline & & $\mathrm{Ya}$ & Tidak \\
\hline \multirow{3}{*}{$\begin{array}{l}\text { Kelas } \\
\text { Aktual }\end{array}$} & Ya & TP & FN \\
\hline & Tidak & FP & TN \\
\hline & Jumlah & $\mathrm{P}$ & $\mathrm{N}$ \\
\hline
\end{tabular}

Gambar 3. Confusion Matrix

Perhitungan nilai akurasi, precission dan reccal dinyatakan dalam persamaan berikut:

Accuracy $=\frac{T P+T N}{P+N}$
Precission $=\frac{T P}{T P+F P}$

Reccal $=\frac{T P}{P}$

Keterangan:

TP (True Positive) : Jumlah variabel positif yang dilabeli dengan benar oleh classifier

TN (True Negative) : Jumlah variabel negatif yang dilabeli dengan benar oleh classifier

FP (False Positive) : Jumlah variabel negatif yang salah dilabeli oleh classifier

FN (False Negative) : Jumlah variabel positif yang salah dilabeli oleh classifier

$\mathrm{P} \quad$ : Jumlah sampel positif

$\mathrm{N} \quad$ : Jumlah sampel negatif

\section{Hasil dan Pembahasan}

\subsection{Hasil Implementasi Metode K-Nearest Neighbor}

Langkah-lanngkah proses mining menggunakan metode K-Nearest Neighbor pada Tools RapidMiner 5.3 adalah sebagai berikut:

1. Pilih data yang akan diproses (penelitian ini menggunakan data dengan extensi excel).

2. Tentukan kelas data dan label tujuan (kelas tujuan dalam penelitian ini adalah "lama Studi", sehingga nilai atribut yang digunakan pada variabel tersebut adalah "Label". 


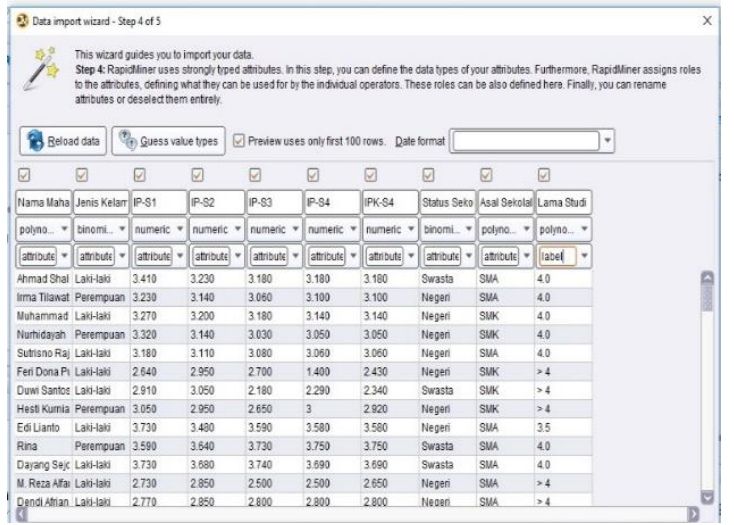

Gambar 4. Penentuan Variabel Tujuan

3. Penerapan Operator yang digunakan

Operator yang digunakan pada tahap ini adalah Discretize by Binning dan $X$-Validation. Operator Discretize by Binning digunakan untuk mengubah nilai data IP-S1, IP-S2, IP-S3, IP-S4 dan IPK-S4, nilainya dibuatkan interval 2. Sedangkan operator $X$-Validation digunakan untuk menghitung kualitas pemodelan dan menghasilkan tingkat keakurasian berdasarkan data set. Konfigurasi proses implementasi pada tool RapidMiner 5.3 menggunakan operator operator Discretize dan operator X-Validation terlihat seperti pada Gambar 5 berikut ini:

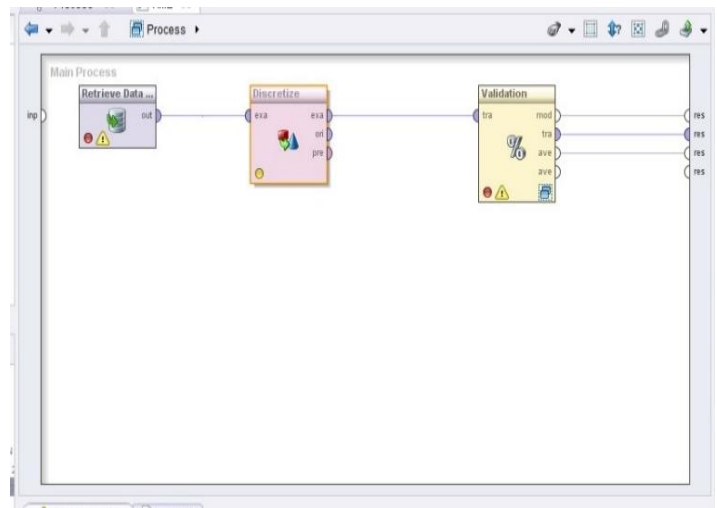

Gambar 5. Penerapan Operator Yang Digunakan

4. Proses Training dan Testing

Tahap ini adalah memilih model klasifikasi yang digunakan, dalam penelitian ini model yang digunakan adalah K-Nearest Neighbor. Proses training dan testing dilakukan dengan cara pada kolom training diterapkan algoritma yang dipilih yaitu K-Nearest Neighbor, sedangkan dikolom testing diterapkan Apply Model dan Performance.

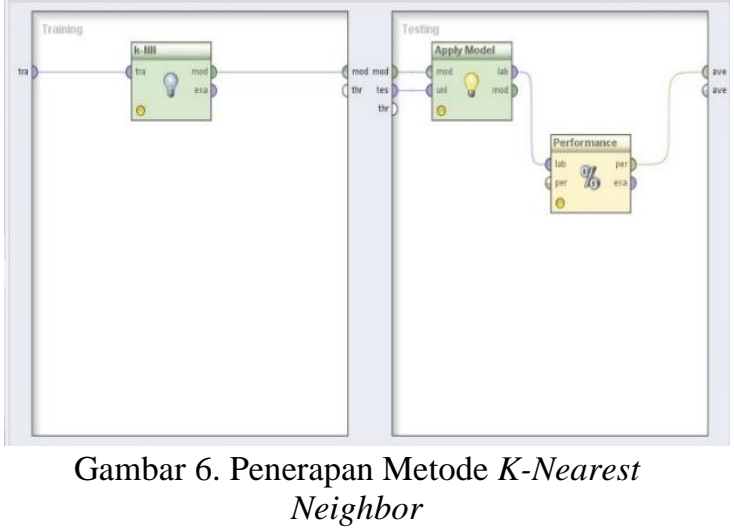

Apply Model berfungsi untuk menjalankan model K-Nearest Neighbor, tahap ini digunakan untuk memproses data training dan data testing. Performance digunakan untuk menghubungkan Apply Model dan melihat hasil akurasi dari model yang digunakan.

\section{Hasil Akurasi Implementasi Metode KNN}

Implementasi metode $K$-Nearest Neighbor pada Tools RapidMiner menghasilkan nilai akurasi sebesar 53,08\% yang dievaluasi menggunakan Confussion Matrix. Gambar 7 menampilkan detail hasil proses mining menggunakan metode $K$-Nearest Neighbor.

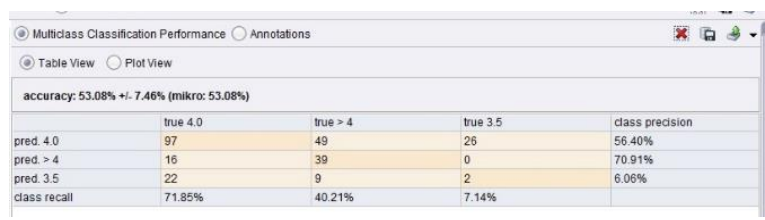

Gambar. 7 Nilai Akurasi Metode K-Nearest Neighbor

Dari hasil implementasi metode K-Nearest Neighbor diperoleh tingkat akurasi sebesar 53,08\% yang dievaluasi berdasarkan confussion matrix. Dari 260 data set, terdapat 97 data yang sesuai prediksi yaitu Lama Studi $=4$ tahun, 49 data yang diprediksi Lama Studi $=4$ tahun ternyata masuk dalam klasifikasi Lama Studi $=>4$ tahun dan 26 data yang diprediksi Lama Studi $=4$ tahun ternyata termasuk dalam klasifikasi Lama Studi $=3.5$ tahun. Yang kedua prediksi Lama Studi $=>4$ tahun terdapat 39 data yang sesuai, yang diprediksi Lama Studi $=>4$ tahun ternyata masuk dalam klasifikasi Lama Studi $=4$ tahun sebanyak 16 data dan yang diprediksi Lama Studi $=>4$ tahun ternyata masuk dalam klasifikasi Lama Studi $=3.5$ tahun tidak ada. Yang terakhir yaitu prediksi Lama Studi $=3.5$ tahun terdapat 2 data yang sesuai prediksi, yang diprediksi Lama Studi $=3.5$ tahun ternyata masuk dalam klasifikasi Lama Studi $=4$ tahun sebanyak 22 data dan yang diprediksi Lama Studi $=3.5$ tahun ternyata masuk dalam klasifikasi Lama Studi $=>4$ tahun sebanyak 9 data.

Akurasi merupakan proporsi tuple positif yang diidentifikasi benar terhadap jumlah semua tuple. Nilai akurasi yang diperoleh dari implementasi metode 
K-Nearest Neighbor berdasarkan confussion matrix menghasilkan akurasi 53,08\% yang diperoleh dari perhitungan berikut ini:

$$
\begin{aligned}
& \text { Accuracy }=\frac{T P+T N}{P+N} \\
& \text { Accuracy }=\frac{97+39+2}{135+97+28}
\end{aligned}
$$

\subsection{Hasil Implementasi Metode Decision Tree}

Langkah-lanngkah proses mining menggunakan metode Decision Tree pada Tools RapidMiner 5.3 adalah sebagai berikut:

1. Pilih data yang akan diproses (penelitian ini menggunakan data dengan extensi excel).

2. Tentukan kelas data dan label tujuan (kelas tujuan dalam penelitian ini adalah "lama Studi", sehingga nilai atribut yang digunakan pada variabel tersebut adalah "Label".

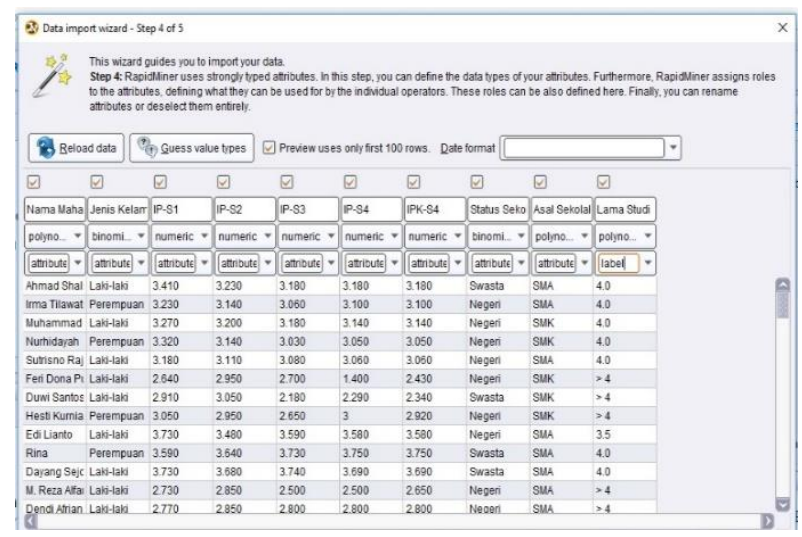

Gambar 8. Penentuan Variabel Tujuan

3. Penerapan Operator yang digunakan

Operator yang digunakan pada tahap ini adalah Discretize by Binning dan X-Validation. Operator Discretize by Binning digunakan untuk mengubah nilai data IP-S1, IP-S2, IP-S3, IP-S4 dan IPK-S4, nilainya dibuatkan interval 2. Sedangkan operator $X$-Validation digunakan untuk menghitung kualitas pemodelan dan menghasilkan tingkat keakurasian berdasarkan data set. Konfigurasi proses implementasi pada tool RapidMiner 5.3 menggunakan operator operator Discretize dan operator X-Validation terlihat seperti pada Gambar 9 berikut ini:

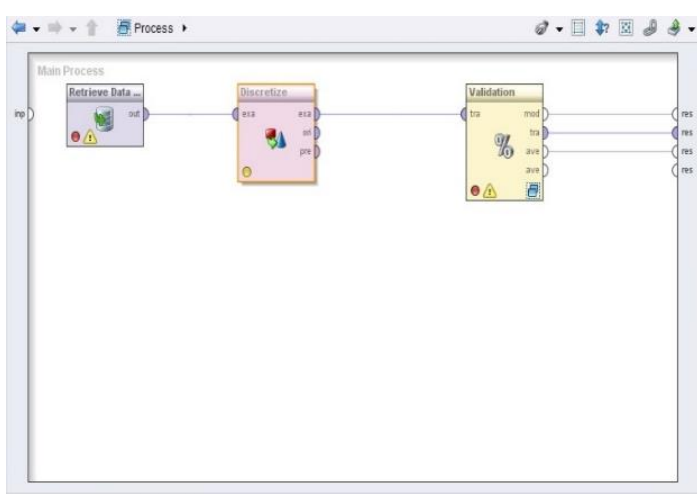

Gambar 9. Penerapan Operator Yang Digunakan

4. Proses Training dan Testing

Tahap ini adalah memilih model klasifikasi yang digunakan, dalam penelitian ini model yang digunakan adalah Decision Tree. Proses training dan testing dilakukan dengan cara pada kolom training diterapkan algoritma yang dipilih yaitu Decision Tree, sedangkan dikolom testing diterapkan Apply Model dan Performance.

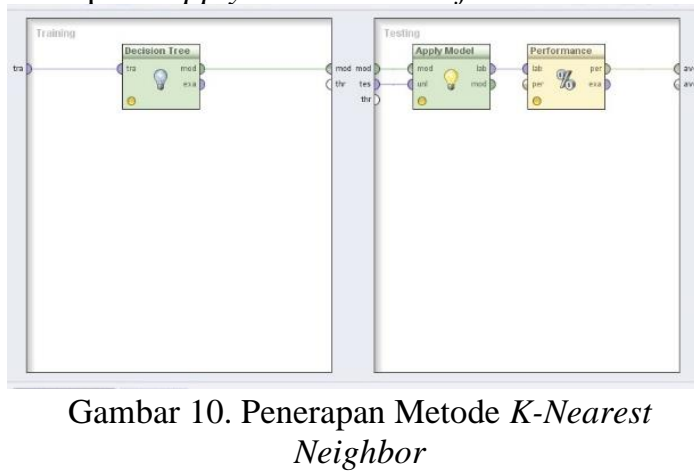

Apply Model berfungsi untuk menjalankan model Decision Tree, tahap ini digunakan untuk memproses data training dan data testing. Performance digunakan untuk menghubungkan Apply Model dan melihat hasil akurasi dari model yang digunakan.

\section{Hasil Akurasi Implementasi Metode Decision Tree}

Implementasi metode Decision Tree pada Tools RapidMiner menghasilkan nilai akurasi sebesar 60,38\% yang dievaluasi menggunakan Confussion Matrix. Gambar 11 menampilkan detail hasil proses mining menggunakan metode Decision Tree.

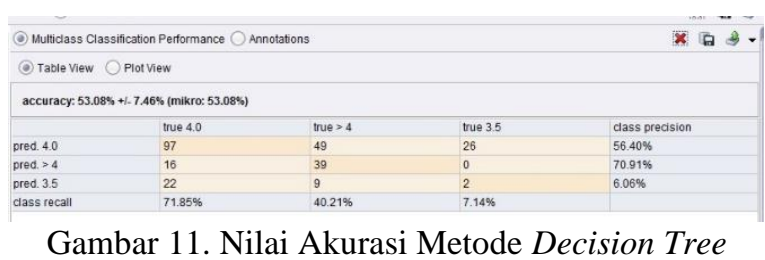

Dari hasil implementasi metode Decision Tree diperoleh tingkat akurasi sebesar $60,38 \%$ yang dievaluasi berdasarkan confussion matrix. Dari 260 data set, 
terdapat 135 data yang sesuai prediksi yaitu Lama Studi 5. Kesimpulan

$=4$ tahun, 75 data yang diprediksi Lama Studi $=4$ tahun

ternyata masuk dalam klasifikasi Lama Studi $=>4$ tahun 5.1 Simpulan

dan 28 data yang diprediksi Lama Studi $=4$ tahun

ternyata termasuk dalam klasifikasi Lama Studi $=3.5$

tahun. Yang kedua prediksi Lama Studi $=>4$ tahun

terdapat 22 data yang sesuai, yang diprediksi Lama Studi

$=>4$ tahun ternyata masuk dalam klasifikasi Lama Studi

$=4$ tahun tidak ada dan yang diprediksi Lama Studi $=>4$

tahun ternyata masuk dalam klasifikasi Lama Studi $=3.5$

tahun juga tidak ada. Yang terakhir yaitu prediksi Lama

Studi $=3.5$ tahun, tidak ada data yang sesuai dengan

yang diprediksi.

Kesimpulan dari penelitian ini bahwa hasil prediksi lama studi mahasiswa pada STMIK Bina Nusantara Jaya Lubuklinggau berdasarkan data set yang diimplementasikan dengan metode K-Nearest Neighbor menunjukan nilai Accuracy yaitu 53,08\%. dan prediksi menggunakan metode Decision Tree diperoleh nilai Accuracy yang lebih besar yaitu 60,38\%. Karena Decision Tree memiliki nilai akurasi yang lebih besar dibandingkan dengan nilai akurasi metode K-Nearest Neighbor maka metode Decision Tree Akurasi merupakan proporsi tuple positif yang direkomendasikan untuk digunakan dalam diidentifikasi benar terhadap jumlah semua tuple. Nilai menyelesaikan masalah prediksi lama studi mahasiswa akurasi yang diperoleh dari implementasi metode pada STMIK Bina Nusantara Jaya Lubuklinggau.

Decision Tree berdasarkan confussion matrix menghasilkan akurasi $60,38 \%$ yang diperoleh dari perhitungan berikut ini:

$$
\begin{aligned}
\text { Accuracy } & =\frac{T P+T N}{P+N} \\
\text { Accuracy } & =\frac{135+22+0}{135+97+28} \\
\text { 5. Accuracy } & =\frac{157}{260} \\
\text { 6. Accuracy } & =0,6038 \\
\text { 7. Accuracy } & =60,38 \%
\end{aligned}
$$

\subsection{Perbandingan Hasil Akurasi Metode K-Nearest Neighbor dan Decision Tree}

\subsection{Saran}

Untuk pengembangan dan penelitian selanjutnya, penulis memberikan beberapa saran, yang pertama sebaiknya jumlah data perlu ditambah guna meningkatkan nilai Accuracy. Yang kedua, yaitu bukan hanya faktor intern atau faktor akademik saja yang dijadikan sebagai variabel atau kriteria namun faktor eksternal misalnya status bekerja, status pernikahan, faktor pembiayaan, dll perlu dijadikan sebagai variabel atau kriteria. Selanjutnya penelitian sejenis dapat dilakukan dengan menerapkan metode data mining yang berbeda dengan metode yang telah penulis gunakan. Dan untuk pengembangan penelitian dapat dilakukan dengan mengadopsi hasil prediksi untuk dijadikan sebagai Hasil dari implementasi yang telah dilakukan, pendukung dalam proses pengambilan keputusan oleh

\begin{tabular}{|c|c|c|}
\hline No & Metode & Nilai Akurasi \\
\hline 1 & K-Nearest Neighbor & $53,08 \%$ \\
\hline 2 & Decision Tree & $63,38 \%$ \\
\hline
\end{tabular}
perbandingan tingkat akurasi antara metode $K$-Nearest para pemangku keputusan.

Neighbor dan Decision Tree:

Tabel 5. Perbandingan Nilai Akurasi Metode K-Nearest Neighbor dan Decision Tree

\section{Daftar Rujukan}

A. Azahari, Y. Yulindawati, D. Rosita, and S. Mallala, "Komparasi Data Mining Naive Bayes dan Neural Network memprediksi Masa Studi Mahasiswa S1," J. Teknol. Inf. dan Ilmu Komput., vol. 7, no. 3, p. 443, 2020.

[2] S. Gunawan and P. Palupiningsih, "Pembentukan Model Klasifikasi Data Lama Studi Mahasiswa Stmik Indonesia Menggunakan Decision Tree," pp. 116-121, 2017.

Berdasarkan tabel diatas, prediksi lama studi mahasiswa
menggunakan metode Decision Tree memiliki nilai akurasi yang lebih tinggi dibandingkan dengan nilai akurasi metode K-Nearest Neighbor yaitu 63,38\%. Hal [3] ini sejalan dengan penelitian yang telah dilakukan oleh [7] dan penelitian yang dilakukan oleh [12] dimana nilai akurasi metode Decision Tree lebih besar dari metode $K$ Nearest Neighbor.

S. Salmu and A. Solichin, "Prediksi Tingkat Kelulusan Mahasiswa Tepat Waktu Menggunakan Naïve Bayes : Studi Kasus UIN Syarif Hidayatullah Jakarta Prediction of Timeliness Graduation of Students Using Naïve Bayes : A Case Study at Islamic State University Syarif Hidayatullah Jakarta," no. April, pp. 701709, 2017.

[4] M. Zainuddin and A. Noercholis, "Studi komparasi algoritma decesion tree (c4.5) dengan algoritma k-nn dalam memprediksi kelulusan tepat waktu mahasiswa," vol. 10, 2019.

[5] D. P. Mulya, "Analisa dan Implementasi 
Association Rule Dengan Algoritma FP- [10] Growth," vol. 1, no. 1, pp. 47-57, 2019.

[6] D. P. I. Putri, D. Anggreani, and A. prasetya Wibawa, "PREDIKSI LAMA STUDI MENGGUNAKAN NAÏVE BAYES,” vol. 2, [11] no. 1, pp. 41-50, 2020.

[7] D. L. Syarif and K. Umam, "Perbandingan Tingkat Akurasi Prediksi Aritmia dengan Menggunakan Algoritma K-Nearest Neighbor [12] dan," no. Snik, pp. 10-15, 2020.

[8] D. M. Meliala and P. Hasugian, "Perbandingan Algoritma K-Nearest Neighbor Dengan Decision Tree Dalam Memprediksi Penjualan Makanan Hewan Peliharaan Di Petshop Dore Vet Clinic," vol. XV, no. November, pp. 35-39, 2020.

[9] A. Budiyantara, Irwansyah, E. Prengki, P. A. Pratama, and N. Wiliani, "KOMPARASI ALGORITMA DECISION TREE , NAIVE BAYES DAN K-NEAREST NEIGHBOR UNTUK MEMPREDIKSI MAHASISWA LULUS,” vol. 5, no. 2, pp. 265-270, 2020.
A. Rohman and M. Rochcham, "KOMPARASI METODE KLASIFIKASI DATA MINING UNTUK PREDIKSI Abstrak," vol. 5, no. 1, pp. 23-29, 2019.

M. S. Maulana, R. Sabarudin, and W. Nugraha, "Prediksi Ketepatan Kelulusan Mahasiswa Diploma dengan Komparasi Algoritma Klasifikasi," vol. 7, no. 3, pp. 202-206, 2019. S. Widaningsih, "PERBANDINGAN METODE DATA MINING UNTUK PREDIKSI NILAI DAN WAKTU KELULUSAN MAHASISWA PRODI TEKNIK INFORMATIKA," vol. 13, no. 1, pp. 16-25, 2019.

[13] M. Zainuddin, "Perbandingan 4 Algoritma Berbasis Particle Swarm Optimization ( pso ) Untuk Prediksi Kelulusan Tepat Waktu Mahasiswa," vol. 13, no. 1, pp. 1-12, 2019.

[14] M. Windarti and A. Suradi, "Perbandingan Kinerja 6 Algoritme Klasifikasi Data Mining untuk Prediksi Masa Studi Mahasiswa," Telematika, vol. 12, no. 1, p. 14, 2019. 